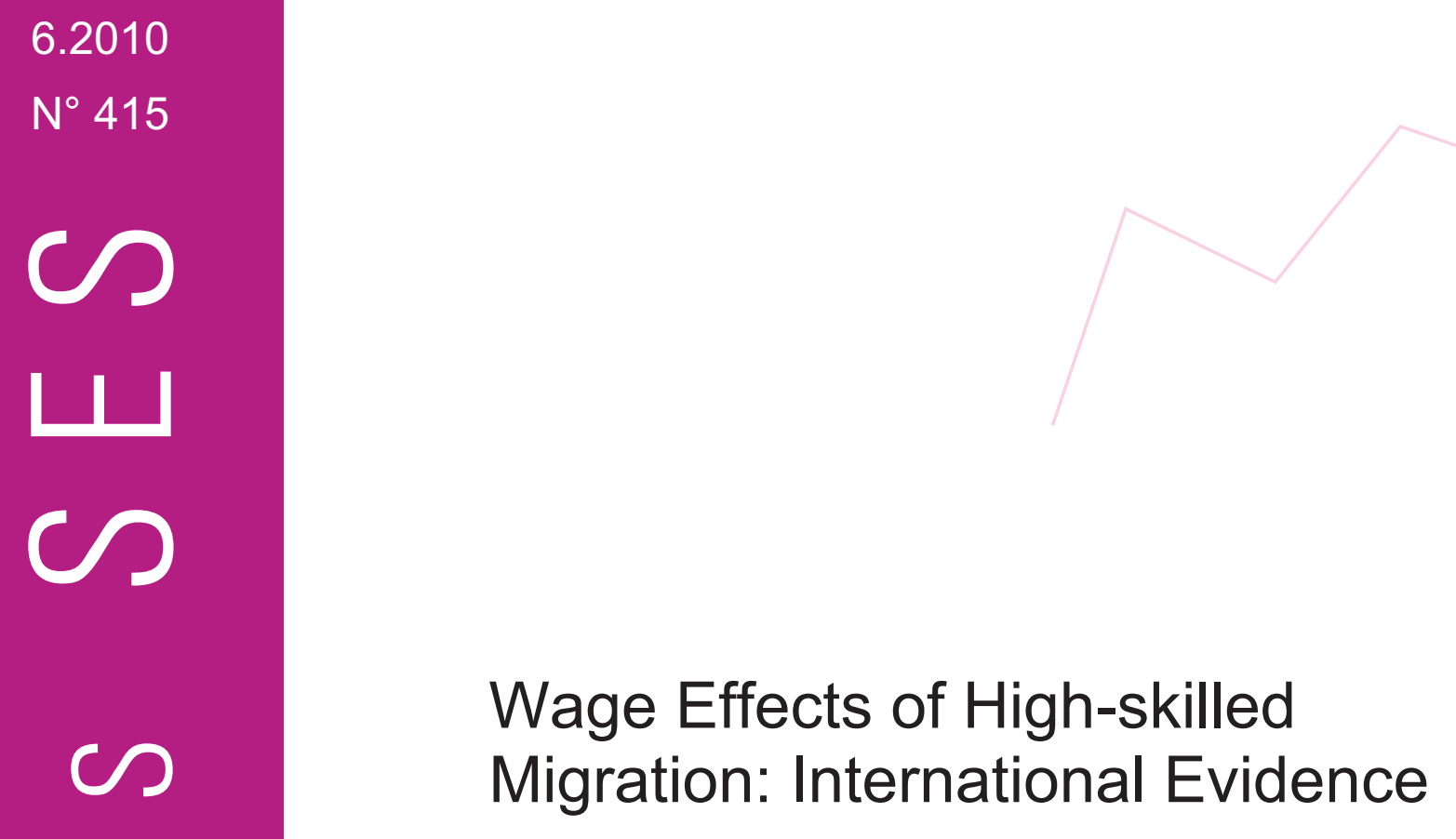

- Volker Grossmann and David Stadelmann

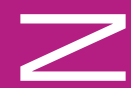

Faculté des Sciences Economiques et Sociales Wirtschafts- und Sozialwissenschaftliche Fakultät Université de Fribourg | Universität Freiburg 


\title{
Wage Effects of High-skilled Migration: International Evidence*
}

\author{
Volker Grossmann ${ }^{\dagger}$ and David Stadelmann ${ }^{\ddagger}$
}

May 26, 2010

\begin{abstract}
This paper argues that international migration of high-skilled workers triggers productivity effects at the macro level such that the wage rate of skilled workers may well rise in host countries and decline in source countries. We exploit a recent data set on international bilateral migration flows and provide evidence which is consistent with this hypothesis. In order to identify the causal effect of migration on wages, we propose different instrumentation strategies which address the endogeneity problem arising from the fact that international wage differences affect migration decisions.

Key words: International high-skilled migration; Wage effects; Total factor productivity.
\end{abstract}

JEL classification: F22; O30.

*Acknowledgements: We are grateful to Michel Beine, Bruno S. Frey, Mark Gradstein, Hillel Rapoport, Avi Simhon, and John Wilson for comments and suggestions on an earlier draft. We also benefited from discussion with seminar participants at the Ben-Gurion University, University of Zurich, University of Geneva, University of Siegen, the Annual Meeting of the European Economic Association in Milan, and the conference "Globalization and the Brain Drain. Theory, Evidence and Policy" in Jerusalem and Ramat Gan.

${ }^{\dagger}$ University of Fribourg; CESifo, Munich; and Institute for the Study of Labor (IZA), Bonn. Postal adress: University of Fribourg, Departement of Economics, Bd. de Pérolles 90, G424, 1700 Fribourg, Switzerland. Tel.: +41 (026) 3009383. Email: volker.grossmann@unifr.ch

${ }_{\ddagger}^{\ddagger}$ University of Fribourg, Departement of Economics, Bd. de Pérolles 90, F410, 1700 Fribourg, Switzerland. Tel.: +41 (026) 3009382. Email: david.stadelmann@unifr.ch 


\section{Introduction}

The recent surge in international migration of high-skilled workers not only raised the standard concern about adverse brain drain effects for developing countries but also led to worries of native high-skilled workers in advanced destination countries. ${ }^{1}$ Domestic workers with higher education levels are afraid to see their wages decline in response to increased competition from similarly qualified migrants. Whereas debates on migration have centered around asylum rights and low-skilled migrants in the past, over the years politicians and mass media discovered the issue of high-skilled immigration. For instance, In Switzerland and Austria, the discussion recently has become emotionally charged due to significant inflows of tertiary educated workers particularly from Germany. ${ }^{2}$ For the US, Hanson, Scheve and Slaughter (2009) find that skilled natives tend to oppose immigration more in states with a relatively skilled mix of immigrants than in states in which the skill composition of immigrants features a high proportion of low-skilled immigrants. Similarly, a recent panel study by Müller and Tai (2010) for Europe suggests that higher-skilled workers have less favorable attitudes towards immigration, the more skilled the immigrants are relative to average skill level in the destination country.

This paper examines the question whether domestic skilled workers have reason to oppose high-skilled immigration and, vice versa, whether non-migrating high-skilled workers win or lose from brain drain in source countries. We argue that international migration of high-skilled workers triggers productivity effects at the macro level such that the wage rate of skilled workers may well rise in host countries and decline in source countries. By exploiting a recent data set on international bilateral migration flows (Docquier, Marfouk and Lowell, 2007), we empirically examine the impact of an increase in high-skilled emigration rates on differences in both $(\log )$ wage income of skilled workers and per capita income between pairs of source and destination countries. We propose a wide range of instrumental variables to address the potential reverse causality problem

\footnotetext{
${ }^{1}$ The number of tertiary educated immigrants living in OECD countries has increased from 12.5 million in the year 1990 to 20.4 million in 2000 (Docquier and Marfouk, 2006). Half of the skilled migrants resided in the US and about a quarter in other Anglo-Saxon countries.

${ }^{2}$ High-skilled immigration surged in Switzerland after Switzerland entered in 2005 a bilateral agreement with the EU on the free movement of labor.
} 
which arises from the fact that international wage differences affect individual migration decisions (e.g., Lucas, 2005; Grogger and Hanson, 2008; Egger and Radulescu, 2009).

We derive a structural empirical model from a theoretical framework which suggests that, even when taking adjustments in educational decisions into account, an increase in high-skilled emigration (immigration) lowers (raises) the domestic skill-intensity in production. ${ }^{3}$ This has two effects on relative wages of the high-skilled between destination and source economy. First, for a given total factor productivity (TFP) and as a consequence of declining marginal productivity of a certain type of labor, high-skilled workers lose in the destination and win in the source economy. Second, however, external effects of migration on TFP (positive in destination, adverse in source) may reverse this result. The net effect of high-skilled migration on international wage differences is thus theoretically ambiguous. This makes the relationship between high-skilled migration and wages an empirical question. Our empirical analysis suggests that, if anything, the external productivity effect dominates.

Our findings are consistent with recent literature on wage effects of high-skilled immigration in single countries. Borjas (2003) and Dustmann, Fabbri and Preston (2005) provide evidence for a small but positive impact of an inflow of immigrants with a college degree on wages for college-educated natives in the US and UK, respectively. In a similar vein, Friedberg (2001) shows that native wages rise when immigrants enter high-skilled occupations in the Israeli labor market. Our contribution shows the theoretical possibility of positive wage effects and provides international evidence by exploiting data on bilateral migration between country pairs, thereby complementing single-country studies on labor market effects of immigration.

The remainder of this paper is organized as follows. Section 2 presents a simple theoretical model. The model provides the basis for the structural estimation in section 3 of the effects of higher emigration on relative wage income as well as relative GDP per capita between source and destination. The last section provides concluding remarks.

\footnotetext{
${ }^{3}$ Grossmann and Stadelmann (2010) develop an overlapping-generations model with endogenous education choice which shows how migration is triggered by a decrease in mobility costs of high-skilled workers and how it may evolve over time. In the present paper we focus empirically on the effect of higher international migration on wages for skilled labor.
} 


\section{Theoretical Considerations}

Our theroretical analysis shows that the presence of external productivity effects through education implies that the wage level of educated workers may rise in the host country in response to an increase in high-skilled migration and may fall in the source country.

\subsection{Set Up}

Consider an economy with a unit mass of individuals, indexed by $i$. Each individual decides whether to become high-skilled, which may require both pecuniary costs $e \geq 0$ (equal for all individuals) in terms of a homogenous consumption good and non-pecuniary (effort) costs which may differ across individuals. High-skilled individuals may emigrate, but derive lower utility for a given income earned abroad than when staying at home (representing mobility costs). ${ }^{4}$ Individuals take the migration opportunity into account when deciding on education.

Formally, for a given income level $y_{i}$, indirect utility of individual $i$ is given by

$$
V_{i}=\left\{\begin{array}{c}
\tilde{v}_{i}\left(y_{i}\right) \text { if } i \text { migrates } \\
v_{i H}\left(y_{i}\right) \text { if } i \text { does not migrate and is skilled } \\
v_{i L}\left(y_{i}\right) \text { if } i \text { remains unskilled }
\end{array}\right.
$$

where we assume $\tilde{v}_{i}(y)<v_{i H}(y)<v_{i L}(y)$ for all $y$ and $i$. Functions $\tilde{v}_{i}, v_{i H}$ and $v_{i L}$ are increasing in income.

The consumption good is chosen as numeraire. Output $Y$ is produced under perfect competition according to the technology

$$
Y=A F(H, L) \equiv A L f(k)
$$

where $H$ and $L$ denote high-skilled and low-skilled labor input, respectively, $A$ is total factor productivity taken as given by the representative firm, function $F$ is linearly homogenous, $k \equiv H / L$ denotes the skill-intensity of production, and $f(k) \equiv F(k, 1) . f$

\footnotetext{
${ }^{4}$ In order to focus on effects of migration of high-skilled workers, we make the standard assumption in the brain drain literature that low-skilled labor is immobile.
} 
is increasing and concave, and fulfills the standard boundary conditions.

There is a positive external effect of a higher skill-intensity in production, $k$, on total factor productivity:

$$
A=a(k)
$$

where $a$ is an increasing function.

\subsection{Equilibrium Analysis}

Let $w_{H}$ and $w_{L}$ denote the wage rate for high-skilled and low-skilled labor at home, respectively, whereas $w_{H}^{*}$ denotes the wage rate for skilled workers abroad. The marginal non-migrating entrant into education, $\bar{\imath}$, derives the same utility from becoming a skilled worker at home and remaining unskilled, i.e., $v_{\bar{\imath} H}\left(w_{H}-e\right)=v_{\bar{\imath} L}\left(w_{L}\right)$. It follows that the fraction/number of individuals choosing education can be represented by $s=S\left(w_{H}, w_{L}\right)$, where function $S$ is increasing in $w_{H}$ and decreasing in $w_{L}$. Similarly, utility function (1) implies that the number of emigrants (who are all skilled by assumption), $m$, can be represented by $m=M\left(w_{H}^{*}, w_{H}\right)$, where $M$ is increasing in foreign wage rate $w_{H}^{*}$ and decreasing in domestic wage rate $w_{H}$ for the skilled.

According to (2), competitive factor prices read

$$
\begin{aligned}
& w_{H}=A f^{\prime}(k), \\
& w_{L}=A\left[f(k)-k f^{\prime}(k)\right] .
\end{aligned}
$$

In labor market equilibrium, the number of domestically born high-skilled individuals is the sum of those working at home and those migrating: $s=H+m$. The number of low-skilled workers is $L=1-s$. Thus, the domestic skill-intensity, $k=H / L$, can be written as $k=\frac{s-m}{1-s}$; equivalently, we can write

$$
s=\frac{k+m}{1+k} \equiv \tilde{s}(k, m)
$$

We find partial derivatives $\tilde{s}_{m}>0$, and using $m<1, \tilde{s}_{k}>0$.

Using $s=S\left(w_{H}, w_{L}\right)$ together with the expressions (4) and (5) for factor prices as 
well as relationship (6) and assumption $A=a(k)$ in (3), we find that the equilibrium skill-intensity is implicitly given as a function of the number of migrants, $m$, by

$$
\tilde{s}(k, m)-B(k)=0
$$

where

$$
B(k) \equiv S\left(a(k) f^{\prime}(k), a(k)\left[f(k)-k f^{\prime}(k)\right]\right)
$$

We write $k \equiv K(m)$ for the solution of (7).

Suppose that function $B$ is decreasing in skill-intensity $k$. For instance, this would be the case if the fraction of skilled individuals $s=S\left(w_{H}, w_{L}\right)$ were dependent on the relative wage rate of non-migrating skilled workers, $w_{H} / w_{L},{ }^{5}$ i.e., if function $S$ were homogenous of degree zero. ${ }^{6}$ It follows that the equilibrium skill-intensity $K(m)$ is decreasing in the number of (skilled) emigrants, $m$, i.e., $K^{\prime}(m)<0$.

According to (3) and (4), the equilibrium wage rate for non-migrating skilled labor is given by

$$
w_{H}=a(K(m)) f^{\prime}(K(m)) \equiv W(m)
$$

It follows for the effect of higher emigration, $m$, on the domestic equilibrium wage rate, $W$, that

$$
W^{\prime}(m)=\left.\left(\frac{a(k) f^{\prime}(k)}{k}[\varepsilon(k)-\eta(k)]\right)\right|_{k=K(m)} K^{\prime}(m),
$$

where $\varepsilon(k) \equiv k a^{\prime}(k) / a(k)$ and $\eta(k) \equiv-k f^{\prime \prime}(k) / f^{\prime}(k)$. Thus, the sign of $W^{\prime}(m)$ is theoretically ambiguous due to two opposing effects. First, for a given total factor productivity (TFP) A, high-skilled workers win in response to higher emigration in the source economy due to a decreasing marginal productivity of skilled labor $(\eta>0)$. Second, however, adverse external productivity effects of migration $(\varepsilon>0)$ in the source

${ }^{5}$ To see this, note from (4) and (5) that

$$
\frac{w_{H}}{w_{L}}=\frac{f^{\prime}(k)}{f(k)-k f^{\prime}(k)}
$$

is decreasing in skill-intensity $k$ and function $S$ is increasing in its first argument.

${ }^{6}$ The properties of function $S$ depend on the distribution of non-pecuniary education costs as captured by utilities $v_{i H}(\cdot)$ in $(1)$. We do not specify utility further. Property $B^{\prime}(k)<0$ indeed holds under a large set of weak conditions, due to declining marginal productivity of labor. 
economy may reverse this result. If $\varepsilon>\eta$, i.e., if the elasticity of productivity $A$ with respect to skill-intensity $k$ exceeds the elasticity of the marginal productivity of skilled labor for a given TFP with respect to $k$, then high-skilled workers see their wages decline with higher emigration. (Recall that the equilibrium skill-intensity, $K(m)$, declines with $m$.) If $\varepsilon<\eta$, the opposite holds.

Consider now a two-country world and denote foreign destination country functions and variables with superscript $\left(^{*}\right)$. That is, let $k^{*}=K^{*}(-m)$ be given by $\tilde{s}\left(k^{*},-m\right)-$ $B^{*}\left(k^{*}\right)=0$ under (net) emigration of $m$ workers to abroad, where function $B^{*}$ is defined analogously to $B$ in (8). The foreign wage rate is

$$
w_{H}^{*}=a^{*}\left(K^{*}(-m)\right)\left(f^{*}\right)^{\prime}\left(K^{*}(-m)\right) \equiv W^{*}(-m)
$$

Then the relative wage rate for skilled workers in the foreign destination relative to the home source country can be written as

$$
\frac{w_{H}^{*}}{w_{H}}=\frac{W^{*}(-m)}{W(m)} \equiv \omega(m)
$$

For instance, if technologies are identical internationally, we find that $\omega(m)$ is increasing in $m$ if and only if $\varepsilon>\eta$, whereas $\omega^{\prime}(m)<0$ if and only if $\varepsilon<\eta$.

The individual migration decision depends on wage differences between countries and the number of migrants is given by $m=M\left(w_{H}^{*}, w_{H}\right)$. At the macro level, however, the effect of high-skilled migration on international (log) wage differences is theoretically ambiguous. The direction of the effect thus is an empirical question addressed in the next section, where we estimate the sign of $\omega^{\prime}(m)$ by employing data on bilateral migration. The potential reverse causality problem which comes from the individual migration decision is addressed by using various instrumentation strategies.

Further remarks are in order. We have not specified the time structure in the theoretical considerations so far. If the model were fully static, equilibrium migration would be the solution to $m=M\left(W^{*}(-m), W(m)\right){ }^{7}$ A shift in migration costs as captured by $\tilde{v}_{i}(\cdot)$ in utility function (1) would shift function $M$ and may trigger an increase in

\footnotetext{
${ }^{7}$ Multiple equilibria and stability issues may arise; see Grossmann and Stadelmann (2008).
} 
the number of emigrants $m$. Being interested in wage effects, this would suggest to estimate a contemporaneous relationsship $w_{H, t}^{*} / w_{H, t}=\omega\left(m_{t}\right)$, where $t$ is the time index. Grossmann and Stadelmann (2010) develop an overlapping-generations framework to theoretically consider the dynamic interaction between international migration and international wage differences for the skilled. In their model, a higher number of intermediate good firms induces specialization gains which raise TFP after some lag and high-skilled emigration has adverse effects on the foundation of firms. Assuming that the lag is one period, thus, relative wages of the skilled abroad positively depend on lagged emigration: $w_{H, t}^{*} / w_{H, t}=\omega\left(m_{t-1}\right) .{ }^{8}$ Employing the notion that economies are still in transition phases (out-of-steady state) suggests to estimate this relationship rather than the contemporaneous one. In the empirical analysis which now follows, we do both.

\section{Empirical Analysis}

Our theoretical analysis has highlighted the interaction between emigration of highskilled labor and the wage income gap to potential host economies of expatriates. To recall, on the one hand, the individual emigration decision depends on differences of wage income to potential destination economies; formally, the number of migrants is $m=M\left(w_{H}^{*}, w_{H}\right)$. On the other hand, at the macro level, higher emigration of skilled labor may affect international wage differences; formally, we have $w_{H}^{*} / w_{H}=\omega(m)$, where $m$ affects $\omega$ through counteracting channels: external TFP effects and the effect on the marginal productivity of skilled labor.

The direction from wage income differences to migration flows has been examined empirically elsewhere. Two recent papers are notable. First, Grogger and Hanson (2008) provide convincing evidence for the critical role of wage differences between country pairs on emigration patterns of tertiary educated workers. ${ }^{9}$ Second, Beine, Docquier and Ozden (2010) show that, in addition to wage differences, network effects are important for

\footnotetext{
${ }^{8}$ By contrast, relationship $m_{t}=M\left(w_{H, t}^{*}, w_{H, t}\right)$ would remain contemporaneous.

${ }^{9}$ In the working paper version of this article (Grossmann and Stadelmann, 2008), we presented evidence for the interaction between emigration flows and income changes using a structural equation model. However, we looked at the impact of a higher aggregate emigration stock of a country on its per capita income. That is, we did not consider bilateral relationships.
} 
the migration decision for both high-skilled and low-skilled workers. That is, emigrants already living in the destination country positively affect migration flows in a causal way. ${ }^{10}$

Our empirical analysis complements their research by focussing on the opposite direction, i.e., from emigration to international wage differences for skilled workers. The tested hypothesis is that, due to productivity effects, increased migration of high-skilled workers may raise (log) income differences between country pairs even for skilled workers.

\subsection{Data and Estimation Strategy}

The emigration rate of high-skilled individuals is our main explanatory variable. Docquier and Marfouk (2006) have established a dataset of emigration stocks and rates by educational attainment for the years 1990 and 2000. The authors count as emigrants all foreign-born individuals aged at least 25 who live in an OECD country and class them by educational attainment and country of origin. Thus, only emigration into OECD countries is captured, approximately 90 percent of educated migrants in the world. ${ }^{11}$ As we are interested in the bilateral migration pattern of high-skilled individuals, we focus on emigration of the high educational category provided in an extended dataset by Docquier, Marfouk and Lowell (2007). We construct the high-skilled emigration rate from country $i$ to $j$ in year $t$, denoted by $M i g_{i j, t}$, as the stock of skilled emigrants from country $i$ living in (OECD) country $j$ divided by the stock of skilled residents in (source) country $i$ in year $t$.

Denote by $y_{i, t}$ the income measure in country $i$ in year $t$, which is further specified below. We estimate, for a country pair $(i, j)$ :

$$
\log \left(\frac{y_{j, t}}{y_{i, t}}\right)=\beta_{0}+\beta_{1} M i g_{i j, t}+\mathbf{x}_{i j, t-1}^{\prime} \boldsymbol{\beta}_{\mathbf{x}}+u_{i j, t} .
$$

Equation (12) is theoretically motivated by relationship $w_{H}^{*} / w_{H}=\omega(m)$ in (11).

\footnotetext{
${ }^{10}$ This suggests that there exist mobility-cost reducing network effects from communities of people from the same nation and from friends and relatives already living abroad (see also Massey et al., 1993).

${ }^{11}$ See Docquier and Marfouk (2006) for a detailed discussion concerning data collection and construction issues.
} 
The theoretical model suggests that $\beta_{1}>0$ if and only if TFP effects of migration are sufficiently high. $\mathbf{x}_{i j}$ is a vector of other controls potentially affecting log income differences between $i$ and $j$ like relative school enrolment rates, relative investment rates, relative urban population shares, and fixed effects for the source country to capture institutional differences to OECD destination countries. These controls are lagged in the estimation to reduce endogeneity bias. We focus on (the log of) relative wage income in the year 2000 as dependent variable and take the lag to be 10 years. $u_{i j}$ is an error term. As an empirical measure of $(\log )$ relative wage income, $\log \left(\frac{y_{j, t}}{y_{i, t}}\right)$, we would ideally use (log) differences in wages by the education category defined for our main explanatory variable $M i g_{i j, t}$, i.e. we would like to use (log) wages differences for high-skilled individuals. Since incomes by education category are not available to us, we use three different empirical measures. Freeman and Oostendorp (2000) have collected information on earnings by occupation and industry from the International Labor Organization's (ILO) October Inquiry Survey from 1983-1998. In order to correct for differences in how countries report earnings, Freeman and Oostendorp (2000) use a standardization procedure to make the data comparable across countries and time. In 2005 they provided an update for their earnings measures for the 1983-2003 ILO October Inquiry data using an improved version of the standardization procedure and the application of country-specific data type correction factors. ${ }^{12}$ For each country, we take Freeman and Oostendorp's earnings measures corresponding to the 80th and the 90 th percentile as two measures for wages of high-skilled workers. ${ }^{13}$ For most countries, data are available for a just a few years. Thus, for each country we take the mean across the period between the years 1995 to 2003 and create a dataset of 89 destination and 23 source countries for the year $2000 .{ }^{14}$ The two constructed $(\log )$ relative wage variables for the 80 th and the 90th percentile are denoted by RelWage $80_{i j, t}$ and RelWage $90_{i j, t} \cdot{ }^{15}$ Productivity effects of brain drain

\footnotetext{
${ }^{12}$ A detailed technical documentation of the standardization procedure for the 1983-2003 ILO October Inquiry data is available online on http://www.nber.org/oww/.

${ }^{13}$ Freeman and Oostendorp report different series of their earnings. We use the series "country-specific calibrations with imputation in US\$".

${ }^{14}$ We also included Turkey where data for the year 1994 was used.

${ }^{15}$ One may argue that migrating skilled workers do not receive wage income in the same percentile than at home, i.e., someone working in the 80th percentile at home earns wage income in, say, the 60 th percentile abroad. Using corresponding alternative relative wage measures leads to very similar results
} 
as captured in our theoretical model may also be reflected when looking at differences in (log) relative GDP per capita. We estimate the effects of bilateral migration on this

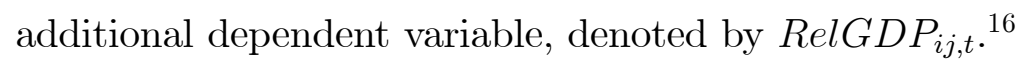

Variable definitions, data sources and summary statistics of the employed variables are presented in Tab. 1.

\section{$<$ Table $1>$}

As indicated, while recent empirical literature has focussed on the impact of income differences on migration patterns, we aim to examine the opposite channel. Thus, the empirical analysis needs to address potential endogeneity bias. In a first attempt to deal with endogeneity, we replace the high-skilled emigration rate in 2000 by the lagged one in 1990 in OLS regressions. Moreover, as discussed at the end of section 2, thereby we also account for transitional dynamics (towards the steady state) in a dynamic framework where $w_{H t}^{*} / w_{H t}=\omega\left(m_{t-1}\right)$. Also this requires to replace $M i g_{i j, t}$ in (12) by the lagged emigration rate $M i g_{i j, t-1}$.

Second, and more importantly, we instrument the high-skilled emigration rate for the year 2000. We use the lagged rate of total expatriates who emigrated from country $i$ to $j$, TotalMigij,t-1, as an instrument for $M i g_{i j, t}$ thereby predicting the rate of high-skilled emigrants by the lagged rate of all emigrants. This can be motivated by the notion that a larger percentage of emigrants from a certain source country already living abroad act as a signal to potential high-skilled migrants concerning openness, treatment of foreigners by administrative bodies, and perceived social links in the destination. Moreover, a higher rate of emigrants to a certain destination creates mobility-cost reducing network effects for emigrants of small source countries. ${ }^{17}$ TotalMig $_{i j, t-1}$ also measures other intangible factors unrelated to income such as reputation, cultural proximity, and social openness to migrants of the destination as perceived by emigrants of the source country.

\footnotetext{
than the one reported.

${ }^{16}$ Using GDP data rather than wage data also has the advantage that the number of observations increases due to better data availablity.

${ }^{17}$ Another way to capture the effect of mobility-cost reducing network effects is to use stocks instead of rates (e.g. Massey et al., 1993; Beine, Docquier and Ozden, 2010). In supplementary material (available upon request), we also provide estimates with the (log) stock of total emigrants. Results are basically unchanged.
} 
The past total emigration rate should not influence contemporaneous income differences beyond the impact exerted by high-skilled emigration itself. The simultaneous use of two or more instruments allows us to check the empirical validity of this condition through J-tests. We employ indicators for geographical factors $\left(\right.$ Dist $_{i j}$, Contig $\left._{i j}\right)$ and linguistic proximity $\left(\mathrm{ComLang}_{i j}\right)$ which are typically used in the literature on migration as additional instruments. These instruments are supposed to capture migration costs (which in the theoretical model were captured by assumption $\tilde{v}_{i}(\cdot)<v_{i H}(\cdot)$ for utility levels in (1)).

In a third attempt to address potential endogeneity bias, we use the total emigration rate in 1960 as instrument, which, however, cannot be readily observed. We construct two proxies for the total emigration rate. Denote by $N e t M i g_{i, 1960}$ the total net emigration rate (number of emigrants minus number of immigrants divided by population size) in country $i$ in the year 1960, provided by the United Nations Population Division. ${ }^{18}$ The first proxy of bilateral total emigration rates in 1960 is defined by

$$
\text { TotalMigP } 1_{i j, 1960}:=\frac{\text { NetMig }_{i, 1960} \times \operatorname{Pop}_{j, 1960}}{\operatorname{Pop}_{i, 1960}}
$$

where $P o p_{i, 1960}$ is population size in the source $i$ and $P o p_{j, 1960}$ is the population size in the destination $j$ in the year $1960 .^{19}$ As argued by Beine, Docquier and Rapoport (2001), one may use countries' population sizes to reflect immigration quotas. NetMig $g_{i, 1960} \times$ $\operatorname{Pop}_{j, 1960}$ thus is a proxy for the net stock of emigrants from country $i$ received in country $j$ in 1960. As our empirical strategy focuses on emigration rates rather than stocks, we divide this measure by population size of source country $i$ to obtain an estimate for the past bilateral emigration rate. As a good instrument, the past total emigration rate should be correlated with the high-skilled emigration rate in 2000, Migij,t. This is supported by calculating partial correlations. The fraction of high-skilled migrants before 1960 was comparatively low and thus potential effects of past migration should only work through induced high-skilled emigration. In other words, the instrument

\footnotetext{
${ }^{18}$ Countries with negative net emigration are coded to have an emigration rate equal to zero.

${ }^{19}$ The construction of the first proxy is inspired by Beine, Docquier and Ozden (2010). They use a similarly constructed proxy as an instrument for the total diaspora of migrants in 1990 (rather than the high-skilled emigration rate).
} 
should be uncorrelated with the dependent variable which is supported by J-tests.

We also construct a second proxy of bilateral emigration rates. We explain the observed the bilateral (log) total emigration stock in $1990^{20}$ in a linear regression model with the following variables: distance between two countries $\left(D i s t_{i j}\right)$, common language $\left(\right.$ ComLang $\left._{i j}\right)$, diplomatic representations between 1946 and 1960 as well as the total number of militarized interstate dispute between the same period from the Correlates of War Project (Ghosn, Palmer and Bremer, 2004). Using the resulting coefficient values without a constant, we predict total bilateral emigration from $i$ to $j$ from the estimated model and add the value of the product $N e t M i g_{i, 1960} \times P o p_{j, 1960}$. The sum is divided by the population of the source country $i$ in $1960\left(P o p_{i, 1960}\right)$ to obtain a second proxy for the bilateral emigration rate in the year 1960. This proxy thus accounts for geographical factors and historical factors. It is denoted by TotalMigP $2_{i j, 1960}$.

\subsection{Results}

Reported standard errors from all estimates account for destination clusters, following Grogger and Hanson (2008), among others. ${ }^{21}$

\section{$<$ Table 2 $>$}

Tab. 2 presents OLS estimates of equation (12). Columns (1), (4), and (7) estimate the effect of the high-skilled emigration rate in the year $2000\left(M i g 2000_{i j}\right)$ for the dependent variables (log of) relative wages in the 80th percentile, relative wages in the 90th

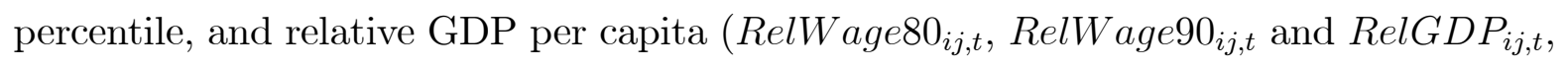
respectively). The coefficient of interest, $\beta_{1}$, is always positive and significantly different from zero at the one percent level. The other columns in Tab. 2 report results when using the lagged high-skilled emigration rate, for $1990\left({\text { Mig } 1990_{i j}}\right)$. This accounts for transitional dynamics and also serves as a first step to account for potential endogeneity. The sizes of coefficient $\beta_{1}$ in these estimations are similar. Thus, an increase in the

\footnotetext{
${ }^{20}$ Like the corresponding emigration rate, TotalMig $g_{i j, t-1}$, the variable is provided in Docquier, Marfouk and Lowell (2007).

${ }^{21}$ We use the Huber-White method to adjust the variance-covariance matrix from our least squares results, to correct for heteroscedasticity and for correlated observations from cluster samples.
} 
high-skilled emigration rate raises (log) income differences between countries. According to our theoretical model, this points to non-negligible TFP effects of high-skilled migration. The control variables of all estimates include the lagged relative school enrolment (primary and tertiary), the relative capital investment and the relative urban population share as well as source fixed effects. The controls have the expected signs apart from primary schooling which is not significant. The relative investment rate and the relative urban population share are typically significantly different from zero. In columns (3), (6) and (9) we exclude the insignificant school enrolment variables and only include significant controls. This increases the number of available country pairs. The coefficients of the high-skilled emigration rate remain significant and increases slightly for all estimates compared to the other results.

The results in Tab. 2 also show that the size of $\beta_{1}$ is similar across specifications for wages in the 80th and 90th percentile. To get a feeling for quantitative effects, with a coefficient $\beta_{1}$ around 0.2 , as suggested by our estimates, doubling the high-skilled emigration rate $\left(\mathrm{Mig}_{i j, t}\right)$ from its mean level of 0.025 (see Tab. 1) implies that relative wages rises by approximately 0.5 percent $(=0.2 \times 0.025) .{ }^{22}$ This effect is rather small, thereby being consistent with the microeconomic estimates of the effect of high-skilled immigration on wages for the high-skilled inside the US by Borjas (2003) and for the UK by Dustmann, Fabbri and Preston (2005). Contrary to the concerns of high-skilled natives in destination countries, the effect is positive rather than negative.

\section{$<$ Table 3 $>$}

Tab. 3 deals with the potential reverse causality problem by providing IV-estimations of (12). In columns (1), (3) and (5) we use the total emigration rate from country $i$ to $j$ in 1990 (TotalMigij,t-1) as single instrument. In the other regressions, measures of geographical factors and linguistic proximity are used as instrument in addion to TotalMigij,t-1. As in Tab. 2 and the following tables, we still control for lagged relative values of school enrolment, private investment and urbanization and include source country fixed effects (results not shown).

\footnotetext{
${ }^{22}$ In fact, between 1990 and 2000 the number of tertiary educated immigrants living in OECD countries almost doubled (Docquier and Marfouk, 2006).
} 
The upper panel of Tab. 3 reports second stage results while the lower panel reports the partial correlations of the additional instruments in the first stage. Columns (1) and (2) present results for relative wages in the 80th percentile. The first column uses the total emigration rate in 1990, TotalMig $_{i j, t-1}$, as a single instrument for the high-skilled emigration rate, $M i g_{i j, t}$, in 2000. The first stage results indicate that the total emigration

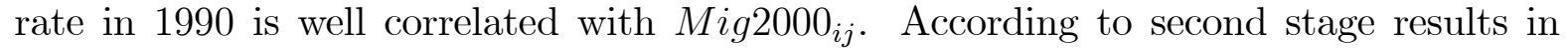
column (1), $\beta_{1}$ is again positive and significantly different from zero at the one percent level. In columns (2), (4) and (6) we use the bilateral geographical distance between $i$ and $j\left(\right.$ Dist $\left._{i j}\right)$, an indicator for a common border $\left(\right.$ Contig $\left._{i j}\right)$ and an indicator for common language of source and destination country $\left(\right.$ ComLang $\left._{i j}\right)$ as additional instruments for $M i g_{i j}$. The coefficient estimate of $\beta_{1}$ in column (2) is again significant, positive and of similar size as in column (1). A F-test for the first stage results shows that the instruments are significantly related to the emigration rate. ${ }^{23}$ Columns (3) and (4) confirm the results for the dependent variable $(\log )$ relative wage in the 90th percentile. The effect of the instrumented high-skilled emigration rate on wage differences is positive and significant in all estimates. Columns (5) and (6) show results with (log) relative GDP differences as a dependent variable. The instrumented variable $M i g_{i j, t}$ again turns out to have a positive and significant effect. None of the J-statistics in Tab. 3, which deal with the overidentifying restrictions, point to problems with the instruments.

Overall, the first stage results suggest that factors potentially unrelated to income such as a destination's reputation, network effects, language and geography drive the high-skilled emigration rate. More importantly, the results of the IV-regressions support our main hypothesis of a causal effect of higher emigration on log wage differences to host economies. Interestingly, the coefficients on the instrumented variable $M i g_{i j, t}$ in Tab. 3 are more than twice as high than in OLS regressions (Tab. 2). This suggests that migrants who arrive through social networks have a particularly high impact on TFP. According to columns (1)-(4) in Tab. 3, doubling the high-skilled emigration rate $\left(M i g_{i j, t}\right)$ from its mean level implies that the relative wage of high-skilled workers abroad

\footnotetext{
${ }^{23}$ That contiguity (variable Contig $_{i j}$ ) has a negative effect on high-skilled emigration in our firststage estimate parallels a similar finding as in Grogger and Hanson (2008). They explain the result by selection and sorting effects.
} 
rises by 1.5 percent $(=0.6 \times 0.025)$.

\section{$<$ Table 4>}

Lagging the total emigration rate as an instrument by more than ten years is supposed to strengthen the argument of the exogeneity of high-skilled emigration rates for between-country income differences. Thus, we examine whether the positive impact of an increase in high-skilled emigration on our relative income measures still holds when the total emigration rate in 1960 is used as instrument. As described above, we use two proxies of the bilateral emigration rate in 1960 for data availability reasons. The results are reported in Tab. 4. The upper panel shows second stage results while the lower panel presents partial correlations of the instruments in the first stage. Columns (1)-(3) focus on $(\log )$ relative wage differences in the 80th percentile. As shown in the lower panel, the constructed proxies TotalMigP $1_{i j, 1960}$ and TotalMigP $2_{i j, 1960}$ for the bilateral total emigration rate in 1960 are well correlated with $M i g_{i j, t}$ and seem to serve as good instruments (see F-tests for columns (1)-(3) and J-test for column (2)). Column (1) again indicates that the relative wage effect of increasing the instrumented high-skilled emigration rate is positive and significant at the one percent level. The same holds when geographical instruments are used together with the proxy variable Total $M i g P 1_{i j, 1960}$, as reported in column (2). Column (3) shows that the size of the coefficient $\beta_{1}$ drops by one half when the second proxy variable TotalMigP $2_{i j, 1960}$ is used as instrument. However, the effect remains positive and significant at the 5 percent level. According the columns (4)-(6), the impact of $M i g_{i j, t}$ on wage differences in the 90th percentile is qualitatively and quantitatively similar to the results for the 80th percentile. The significance level is even always at one percent. Finally, columns (7)-(9) report results for (log) relative GDP per capita differences as a dependent variable. According to the estimates, $\beta_{1}$ is again positive and significantly different from zero in all specifications using different instruments (once at the 10 percent level, if many instruments are included, and otherwise at the one percent level).

We conducted further sensitivity analysis which is available on request. First, instead of using source fixed effects we include regional dummies and a dummy variable which 
indicates whether also the source country belongs to the OECD. Second, we take past migration stocks rather than rates as instruments for the contemporaneous high-skilled emigration rate. Third, we employ an alternative emigration data set by Defoort (2006) while constructing the migration proxies in a similar way as in Tab. 4. Significance and size of the coefficients of interest remain similar in all of these alternative estimations.

\section{$<$ Table 5 $>$}

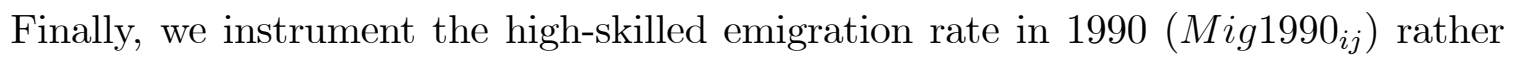
than the one in $2000\left(M_{i g} 2000_{i j}\right)$, again employing the proxies for total emigration in 1960. By doing so, we address potential endogeneity problems in the estimates in Tab. 2

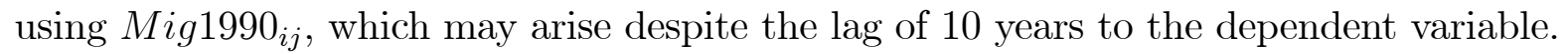
The results are presented in Tab. 5. They show similar results to Tab. 4. Again, the size of the coefficient of interest, $\beta_{1}$, in the IV-estimates are higher than those in the OLS-estimates of Tab. 2.

\section{Concluding Remarks}

In this paper we analyzed the impact of an increase in international bilateral migration of high-skilled workers on relative wage income between pairs of source and destination countries of expatriates. Our theoretical considerations suggested that an increase in the number of migrants may increase international wage inequality by adversely affecting total factor productivity in the source economy and raising it in the host economy. Our empirical analysis provided evidence which is consistent with this hypothesis. Using a data set on bilateral emigration of skilled workers, our results suggest that an increase in high-skilled emigration rates slightly raises wage income for skilled workers in destination relative to source countries in a causal way.

Our paper thereby complements findings from single-country studies by providing international evidence on moderately positive wage effects of high-skilled immigration. At the same time, the evidence points to adverse first-order effects of brain drain for 
non-migrants in source countries. ${ }^{24}$ Regarding source country effects, our analysis reemphasizes the traditional view on brain drain (e.g., Bhagwati and Hamada, 1974). ${ }^{25}$ Regarding destination countries, we do not find empirical support for economic concerns of skilled natives who oppose high-skilled immigration.

\section{References}

[1] Beine, Michel, Frédéric Docquier and Caglar Ozden (2010). Diasporas, Journal of Development Economics, forthcoming.

[2] Beine, Michel, Frédéric Docquier and Hillel Rapoport (2001). Brain drain and economic growth: theory and evidence, Journal of Development Economics 64, 275-89.

[3] Beine, Michel, Fréderic Docquier and Hillel Rapoport (2008). Brain drain and human capital formation in developing countries: winners and losers, Economic Journal 118, 631-652.

[4] Bhagwati, Jagdish N. and Koichi Hamada (1974). The brain drain, international integration of markets for professionals and unemployment, Journal of Development Economics 1, 19-42.

[5] Borjas, George J. (2003). The Labor Demand Curve Is Downward Sloping: Reexamining the Impact of Immigration on the Labor Market, Quarterly Journal of Economics 118, 1335-1374.

[6] Cattaneo, Cristina (2009). International Migration, the Brain Drain and Poverty: A Cross-country Analysis, The World Economy 32, 1180-1202.

\footnotetext{
${ }^{24}$ Second-order effects would include remittances and implications of return migration, for instance. Such effects are not accounted for in our analysis but may be very important to obtain a more complete picture on the net effects of high-skilled migration on source countries.

${ }^{25}$ Recent literature has emphasized positive effects of brain drain for market income in the source economy (e.g., Mountford, 1997; Stark, Helmenstein and Prskawetz, 1997, 1998; Beine, Docquier and Rapoport, 2001, 2008). The possibility arises from the idea that an increase in immigration quotas in advanced countries improves immigration prospects for skilled workers in developing countries and thereby raises incentives to acquire education. Cattaneo (2009) provides a review on the literature on effects of brain drain for the source economy.
} 
[7] Defoort, Cecile (2006). Tendances de long terme en migrations internationales: analyse à partir de 6 pays receveurs, Université Catholique de Louvain (mimeo).

[8] Docquier, Frédéric and Aldeslam Marfouk (2006). International migration by educational attainment (1990-2000) - Release 1.1, in: C. Ozden and M. Schiff (eds), International Migration, Remittances and Development, Palgrave Macmillan, New York.

[9] Docquier, Frédéric, B. Lindsay Lowell and Abdeslam Marfouk (2007). A Gendered Assessment of the Brain Drain, IZA Discussion Papers No. 3235.

[10] Dustmann, Christian, Francesca Fabbri and Ian Preston (2005). The Impact of Immigration on the British Labour Market, Economic Journal 115, F324-F341.

[11] Egger, Peter and Doina Maria Radulescu (2009). The Influence of Labour Taxes on the Migration of Skilled Workers, The World Economy 32, 1365-1379.

[12] Friedberg, Rachel M. (2001). The Impact Of Mass Migration On The Israeli Labor Market, Quarterly Journal of Economics 116, 1373-1408.

[13] Freeman, Richard B. and Remco H. Oostendorp (2000). Wages Around the World: Pay Across Occupations and Countries, NBER Working Paper No. 8058.

[14] Ghosn, Faten, Glenn Palmer, and Stuart Bremer (2004). The MID3 Data Set, 19932001: Procedures, Coding Rules, and Description, Conflict Management and Peace Science 21, 133-154, available on http://www.correlatesofwar.org/.

[15] Grogger, Jeffrey and Gordon H. Hanson (2008). Income maximization and the selection and sorting of international migrants, NBER Working Paper No. 13821.

[16] Grossmann, Volker and David Stadelmann (2008). International mobility of the highly skilled, endogenous R\&D, and public infrastructure investment, IZA Discussion Paper No. 3366. 
[17] Grossmann, Volker and David Stadelmann (2010). Does International Mobility of High-Skilled Workers Aggravate Between-Country Inequality?, Journal of Development Economics, forthcoming.

[18] Hanson, Gordon H., Kenneth Scheve and Matthew J. Slaughter (2009). Individual Preferences over High-Skilled Immigration in the United States, in : in Jagdish Bhagwati and Gordon Hanson, eds., Skilled Immigration Today: Problems, Prospects, and Policies, Oxford University Press, 2009, 207-246.

[19] Lucas, Robert E.B. (2005). International migration and economic development: Lessons from low-income countries, Edward Elgar.

[20] Massey, Douglas S., Joaquín Arango, Graeme Hugo, Ali Kouaouci, Adela Pellegrino and J. Edward Taylor (1993). Theories of international migration: A review and appraisal, Population and Development Review 19, 431-466.

[21] Mayer, Thierry and Soledad Zignago (2006). A note on CEPII's distances measures, Explanatory note, CEPII, Paris.

[22] Mountford, Andrew (1997). Can a brain drain be good for growth in the source economy?, Journal of Development Economics 53, 287-303.

[23] Müller, Tobias and Silvio H.T. Tai (2010). Individual attitudes towards migration: a reexamination of the evidence, University of Geneva, mimeo.

[24] Stark, Oded, Christian Helmenstein and Alexia Prskawetz (1997). A brain gain with a brain drain, Economics Letters 55, 227-234.

[25] Stark, Oded, Christian Helmenstein, Alexia Prskawetz (1998). Human capital depletion, human capital formation, and migration: A blessing in a 'curse'?, Economics Letters 60, 363-367. 


\section{Data description and sources}

\begin{tabular}{|c|c|c|c|c|}
\hline Variable & Description and source & $N$ & Mean & S.D. \\
\hline $\begin{array}{l}\text { Mig2000 }_{i j} \\
{\left[\text { Mig1990 }_{i j}\right]}\end{array}$ & $\begin{array}{l}\text { Stock of emigrants of educational category "high" aged } \\
25+\text { born in country } i \text { and living in OECD country } j \text { in } \\
\text { year } 2000[1990] \text { divided by stock of residents of } \\
\text { educational category "high" in country } i \text { in year } 2000 \\
\text { [1990]. Stock of emigration and stock of residents of } \\
\text { educational category "high" from Docquier, Marfouk } \\
\text { and Lowell (2007). }\end{array}$ & 3052 & 0.0246 & 0.1909 \\
\hline RelWage $8 O_{i j}$ & $\begin{array}{l}\text { Log of wage in 80th percentile of country } j \text { minus } \log \\
\text { of wage in } 80 \text { th percentile of country } i \text { in year } 2000 \text {. } \\
\text { Wage data from Occupational Wages around the } \\
\text { World (OWW) Database. }\end{array}$ & 1247 & 1.2650 & 1.4945 \\
\hline RelWage90 ${ }_{i j}$ & $\begin{array}{l}\text { Log of wage in 90th percentile of country } j \text { minus } \log \\
\text { of wage in } 90 \text { th percentile of country } i \text { in year } 2000 \text {. } \\
\text { Wage data from Occupational Wages around the } \\
\text { World (OWW) Database. }\end{array}$ & 1247 & 1.1810 & 1.3953 \\
\hline $\mathrm{Re} / G D P_{i j}$ & $\begin{array}{l}\text { Log of GDP per capita of country } j \text { minus log of GDP } \\
\text { per capita of country } i \text { in year } 2000 . \text { GDP data from } \\
\text { Penn World Table Version } 6.2 \text {. }\end{array}$ & 3052 & 1.4360 & 1.2890 \\
\hline RelPrimSchool1990 $i j$ & $\begin{array}{l}\text { Primary school enrolment in country } j \text { divided by } \\
\text { primary school enrolment in country } i \text { in year } 1990 . \\
\text { Primary school enrolment rate from Global } \\
\text { Development Finance \& World Development } \\
\text { Indicators. }\end{array}$ & 2403 & 1.2040 & 0.5211 \\
\hline RelTertSchool1990 ij & $\begin{array}{l}\text { Tertiary school enrolment in country } j \text { divided by } \\
\text { tertiary school enrolment in country } i \text { in year } 1990 \text {. } \\
\text { Tertiary school enrolment rate from Global } \\
\text { Development Finance \& World Development } \\
\text { Indicators. }\end{array}$ & 2477 & 10.2700 & 22.2216 \\
\hline RelInvest1990 & $\begin{array}{l}\text { Investment share in country } j \text { divided by investment } \\
\text { share in country } i \text { in year 1990. Investment share from } \\
\text { Penn World Table Version 6.2. }\end{array}$ & 3052 & 2.3350 & 1.9566 \\
\hline RelUrban1990 & $\begin{array}{l}\text { Urban population share in country } j \text { divided by urban } \\
\text { population share in country } i \text { in year } 1990 \text {. Urban } \\
\text { population share from Global Development Finance \& } \\
\text { World Development Indicators. }\end{array}$ & 3013 & 2.0500 & 1.8872 \\
\hline TotalMig & $\begin{array}{l}\text { Emigrant population from country } i \text { living in country } j \\
\text { divided by population in } 1000 \text { of country } i \text { in year } \\
\text { 1990. Docquier, Marfouk and Lowell (2007). }\end{array}$ & 3052 & 1.6870 & 11.1509 \\
\hline Dist $_{i j}$ & $\begin{array}{l}\text { Log geodesic distance in } \mathrm{kms} \text { between country } i \text { and } j \text {. } \\
\text { Mayer and Soledad (2006). }\end{array}$ & 3042 & 8.5170 & 0.9313 \\
\hline ComLangij $_{i j}$ & $\begin{array}{l}\text { Dummy variable capturing if same language is spoken } \\
\text { by at least } 9 \% \text { of the population in country } i \text { and } j \text {. } \\
\text { Mayer and Soledad (2006). }\end{array}$ & 3052 & 0.1311 & 0.3375 \\
\hline Contig $_{i j}$ & $\begin{array}{l}\text { Dummy variable capturing if country } i \text { and } j \text { are } \\
\text { contiguous. Mayer and Soledad (2006). }\end{array}$ & 3052 & 0.0269 & 0.1617 \\
\hline
\end{tabular}

Notes: The range, mean and standard deviations are not weighted and based on the respective number of observations. Destination countries are the 30 OECD members. Total number of observations depends on data availability for destination and source countries. An observation is excluded if bilateral data is not available or source country does not have any emigrant in destination country. 
Table 2

Effect of high skilled emigration rates on income differences between countries

\begin{tabular}{|c|c|c|c|c|c|c|c|c|c|}
\hline \multirow[t]{2}{*}{ Variable } & $\begin{array}{l}\text { OLS } \\
\text { (1) }\end{array}$ & $\begin{array}{l}\text { OLS } \\
(2)\end{array}$ & $\begin{array}{l}\text { OLS } \\
\text { (3) }\end{array}$ & $\begin{array}{l}\text { OLS } \\
\text { (4) }\end{array}$ & $\begin{array}{l}\text { OLS } \\
\text { (5) }\end{array}$ & $\begin{array}{l}\text { OLS } \\
\text { (6) }\end{array}$ & $\begin{array}{l}\text { OLS } \\
\text { (7) }\end{array}$ & $\begin{array}{l}\text { OLS } \\
\text { (8) }\end{array}$ & $\begin{array}{l}\text { OLS } \\
\text { (9) }\end{array}$ \\
\hline & \multicolumn{3}{|c|}{ Dependent variable: RelWage $80_{\mathrm{ij}}$} & \multicolumn{3}{|c|}{ Dependent variable: RelWage $90_{\mathrm{ij}}$} & \multicolumn{3}{|c|}{ Dependent variable: $\mathbf{R e l G D P}_{\mathrm{ij}}$} \\
\hline Mig2000 $i j$ & $\begin{array}{c}0.2169^{a} \\
(0.0490)\end{array}$ & & & $\begin{array}{c}0.2290^{a} \\
(0.0483)\end{array}$ & & & $\begin{array}{c}0.1630^{a} \\
(0.0276)\end{array}$ & & \\
\hline Mig1990 $_{i j}$ & & $\begin{array}{l}0.1645^{\mathrm{b}} \\
(0.0678)\end{array}$ & $\begin{array}{c}0.2452^{\mathrm{b}} \\
(0.1231)\end{array}$ & & $\begin{array}{c}0.1738^{\mathrm{b}} \\
(0.0699)\end{array}$ & $\begin{array}{c}0.2534^{\mathrm{b}} \\
(0.1231)\end{array}$ & & $\begin{array}{c}0.1386^{a} \\
(0.0418)\end{array}$ & $\begin{array}{c}0.1672^{a} \\
(0.0624)\end{array}$ \\
\hline RelPrimSchool1990 $i j$ & $\begin{array}{l}-1.0022 \\
(2.2117)\end{array}$ & $\begin{array}{l}-1.0057 \\
(2.2127)\end{array}$ & & $\begin{array}{l}-0.5458 \\
(2.0325)\end{array}$ & $\begin{array}{l}-0.5495 \\
(2.0336)\end{array}$ & & $\begin{array}{l}-0.3658 \\
(0.7655)\end{array}$ & $\begin{array}{l}-0.3683 \\
(0.7668)\end{array}$ & \\
\hline RelTertSchool1990 & $\begin{array}{c}0.0105 \\
(0.0102)\end{array}$ & $\begin{array}{c}0.0106 \\
(0.0101)\end{array}$ & & $\begin{array}{c}0.0104 \\
(0.0099)\end{array}$ & $\begin{array}{c}0.0105 \\
(0.0099)\end{array}$ & & $\begin{array}{c}0.0046 \\
(0.0028)\end{array}$ & $\begin{array}{l}0.0047^{c} \\
(0.0028)\end{array}$ & \\
\hline RelInvest1990 & $\begin{array}{c}0.4990^{\mathrm{b}} \\
(0.2533)\end{array}$ & $\begin{array}{l}0.4975^{\mathrm{b}} \\
(0.2533)\end{array}$ & $\begin{array}{c}0.5617^{a} \\
(0.2038)\end{array}$ & $\begin{array}{c}0.4356^{c} \\
(0.2430)\end{array}$ & $\begin{array}{l}0.4341^{c} \\
(0.2430)\end{array}$ & $\begin{array}{c}0.4953^{\mathrm{b}} \\
(0.1944)\end{array}$ & $\begin{array}{l}0.2331^{\mathrm{c}} \\
(0.1216)\end{array}$ & $\begin{array}{l}0.2317^{c} \\
(0.1215)\end{array}$ & $\begin{array}{c}0.2995^{\mathrm{a}} \\
(0.0948)\end{array}$ \\
\hline RelUrban1990 ij & $\begin{array}{c}0.6594^{b} \\
(0.3052)\end{array}$ & $\begin{array}{c}0.6587^{\mathrm{b}} \\
(0.3054)\end{array}$ & $\begin{array}{c}0.9347^{a} \\
(0.2484)\end{array}$ & $\begin{array}{c}0.5761^{\mathrm{c}} \\
(0.3015)\end{array}$ & $\begin{array}{l}0.5754^{c} \\
(0.3017)\end{array}$ & $\begin{array}{c}0.8278^{a} \\
(0.2619)\end{array}$ & $\begin{array}{l}0.2113^{a} \\
(0.0805)\end{array}$ & $\begin{array}{c}0.2109^{a} \\
(0.0806)\end{array}$ & $\begin{array}{c}0.2875^{a} \\
(0.0741)\end{array}$ \\
\hline (incercept) & $\begin{array}{c}0.6731 \\
(2.7047)\end{array}$ & $\begin{array}{c}0.6802 \\
(2.7058)\end{array}$ & $\begin{array}{l}-0.7328 \\
(0.6717)\end{array}$ & $\begin{array}{c}0.3170 \\
(2.5903)\end{array}$ & $\begin{array}{c}0.3245 \\
(2.5916)\end{array}$ & $\begin{array}{l}-0.6226 \\
(0.6595)\end{array}$ & $\begin{array}{c}3.6064 \\
(3.0786)\end{array}$ & $\begin{array}{c}3.6211 \\
(3.0845)\end{array}$ & $\begin{array}{c}1.8097^{a} \\
(0.5320)\end{array}$ \\
\hline Origin FE & YES & YES & YES & YES & YES & YES & YES & YES & YES \\
\hline $\mathrm{N}$ & 1010 & 1010 & 1247 & 1010 & 1010 & 1247 & 2275 & 2275 & 3013 \\
\hline Adj. R2 & 0.8476 & 0.8474 & 0.8290 & 0.8446 & 0.8443 & 0.8200 & 0.9395 & 0.9393 & 0.9320 \\
\hline Destination clusters & YES & YES & YES & YES & YES & YES & YES & YES & YES \\
\hline
\end{tabular}


Table 3

Effect of high skilled emigration rates on income differences between countries (instrumental variable estimations)

\begin{tabular}{|c|c|c|c|c|c|c|}
\hline \multirow[t]{2}{*}{ Variable } & $\begin{array}{l}I V \\
(1)\end{array}$ & $\begin{array}{l}I V \\
(2)\end{array}$ & $\begin{array}{l}I V \\
(3)\end{array}$ & $\begin{array}{l}I V \\
(4)\end{array}$ & $\begin{array}{l}I V \\
(5)\end{array}$ & $\begin{array}{l}I V \\
(6)\end{array}$ \\
\hline & \multicolumn{2}{|c|}{$\begin{array}{l}\text { Dependent variable: } \\
\text { RelWage } 80_{\mathrm{ij}}\end{array}$} & \multicolumn{2}{|c|}{$\begin{array}{c}\text { Dependent variable: } \\
\text { RelWage } 90_{\mathrm{ij}}\end{array}$} & \multicolumn{2}{|c|}{$\begin{array}{l}\text { Dependent variable: } \\
\text { RelGDP }_{\mathrm{ij}}\end{array}$} \\
\hline Mig2000 & $\begin{array}{l}0.6026^{a} \\
(0.1457)\end{array}$ & $\begin{array}{l}0.5948^{\mathrm{a}} \\
(0.1406)\end{array}$ & $\begin{array}{l}0.5888^{a} \\
(0.1443)\end{array}$ & $\begin{array}{l}0.5788^{a} \\
(0.1374)\end{array}$ & $\begin{array}{l}0.3036^{c} \\
(0.1601)\end{array}$ & $\begin{array}{l}0.3017^{\mathrm{b}} \\
(0.1532)\end{array}$ \\
\hline Other controls & YES & YES & YES & YES & YES & YES \\
\hline Origin FE & YES & YES & YES & YES & YES & YES \\
\hline $\mathrm{N}$ & 1010 & 1010 & 1010 & 1010 & 2275 & 2266 \\
\hline Adj. R2 & 0.8504 & 0.8507 & 0.8475 & 0.8479 & 0.9396 & 0.9394 \\
\hline Destination clusters & YES & YES & YES & YES & YES & YES \\
\hline F-Test (first stage) & 25.09 & 24.7 & 25.09 & 24.7 & 12.57 & 12.67 \\
\hline J-Test & - & 0.806 & - & 0.673 & - & 0.4611 \\
\hline Instruments used & TotalMigij & $\begin{array}{c}\text { TotalMig }_{i j}+\text { Dist }_{i} \\
+ \text { ComLang }_{i j}+ \\
\text { Contig }_{i j}\end{array}$ & TotalMigij & $\begin{array}{c}\text { TotalMig }_{i j}+\text { Dist }_{i} \\
+ \text { ComLang }_{i j}+ \\
\text { Contig }_{g i j}\end{array}$ & TotalMigij $_{i j}$ & $\begin{array}{c}\text { TotalMigig }_{i j}+\text { Dist }_{i} \\
+ \text { ComLang }_{i j}+ \\
\text { Contig }_{i j}\end{array}$ \\
\hline \multicolumn{7}{|c|}{ First stage results (partial correlations) } \\
\hline TotalMig $g_{i j}$ & $\begin{array}{l}0.0198^{\mathrm{a}} \\
(0.0006)\end{array}$ & $\begin{array}{c}0.0196^{\mathrm{a}} \\
(0.0006)\end{array}$ & $\begin{array}{l}0.0198^{\mathrm{a}} \\
(0.0006)\end{array}$ & $\begin{array}{l}0.0196^{\mathrm{a}} \\
(0.0006)\end{array}$ & $\begin{array}{l}0.0124^{a} \\
(0.0004)\end{array}$ & $\begin{array}{c}0.0123 \\
(0.0004)\end{array}$ \\
\hline Dist $_{i j}$ & & $\begin{array}{l}-0.0099^{d} \\
(0.0057)\end{array}$ & & $\begin{array}{l}-0.0099^{d} \\
(0.0057)\end{array}$ & & $\begin{array}{l}-0.0166^{a} \\
(0.0053)\end{array}$ \\
\hline ComLang $_{i j}$ & & $\begin{array}{l}0.0277 \mathrm{c} \\
(0.0151)\end{array}$ & & $\begin{array}{l}0.0277^{\mathrm{c}} \\
(0.0151)\end{array}$ & & $\begin{array}{l}0.0227^{\mathrm{b}} \\
(0.0108)\end{array}$ \\
\hline Contig $_{i j}$ & & $\begin{array}{l}-0.0772^{a} \\
(0.0236) \\
\end{array}$ & & $\begin{array}{l}-0.0772^{a} \\
(0.0236) \\
\end{array}$ & & $\begin{array}{l}-0.1009^{a} \\
(0.0219) \\
\end{array}$ \\
\hline
\end{tabular}


Table 4

Effect of high skilled emigration rates on income differences between countries (use of proxies)

\begin{tabular}{|c|c|c|c|c|c|c|c|c|c|}
\hline \multirow[t]{2}{*}{ Variable } & $\begin{array}{l}I V \\
(1)\end{array}$ & $\begin{array}{l}I V \\
(2)\end{array}$ & $\begin{array}{l}I V \\
(3)\end{array}$ & $\begin{array}{l}I V \\
(4)\end{array}$ & $\begin{array}{l}I V \\
(5)\end{array}$ & $\begin{array}{l}I V \\
(6)\end{array}$ & $\begin{array}{l}I V \\
\text { (7) }\end{array}$ & $\begin{array}{l}I V \\
(8)\end{array}$ & $\begin{array}{l}I V \\
(9)\end{array}$ \\
\hline & \multicolumn{3}{|c|}{ Dependent variable: RelWage $\mathbf{8 0}_{\mathrm{ij}}$} & \multicolumn{3}{|c|}{ Dependent variable: RelWage $90_{\mathrm{ij}}$} & \multicolumn{3}{|c|}{ Dependent variable: $\mathbf{R e l G D P}_{\mathbf{i j}}$} \\
\hline Mig2000 & $\begin{array}{l}0.7617^{a} \\
(0.2007)\end{array}$ & $\begin{array}{l}0.6676^{a} \\
(0.2124)\end{array}$ & $\begin{array}{l}0.3911^{\mathrm{b}} \\
(0.1649)\end{array}$ & $\begin{array}{c}0.7987^{a} \\
(0.1871)\end{array}$ & $\begin{array}{l}0.6875^{\mathrm{a}} \\
(0.2193)\end{array}$ & $\begin{array}{l}0.4324^{a} \\
(0.1539)\end{array}$ & $\begin{array}{l}0.5679 a \\
(0.1199)\end{array}$ & $\begin{array}{l}0.3883^{c} \\
(0.2371)\end{array}$ & $\begin{array}{l}0.3489^{\mathrm{b}} \\
(0.1719)\end{array}$ \\
\hline Other controls & YES & YES & YES & YES & YES & YES & YES & YES & YES \\
\hline Origin FE & YES & YES & YES & YES & YES & YES & YES & YES & YES \\
\hline $\mathrm{N}$ & 1010 & 1010 & 1010 & 1010 & 1010 & 1010 & 2259 & 2250 & 2259 \\
\hline Adj. R2 & 0.8481 & 0.8484 & 0.8476 & 0.8451 & 0.8455 & 0.8447 & 0.9387 & 0.9384 & 0.9384 \\
\hline Destination clusters & YES & YES & YES & YES & YES & YES & YES & & YES \\
\hline F-Test (first stage) & 15.2 & 15.9 & 16.5 & 15.2 & 15.9 & 16.5 & 13.5 & 14.4 & 14.8 \\
\hline J-Test & - & 0.702 & - & - & 0.471 & - & - & 0.1397 & - \\
\hline Instruments used & TotalMigP1 $1_{i j}$ & $\begin{array}{l}\text { TotalMigPtij } \\
\text { Disti }^{+} \text {ComLang } \\
+ \text { Contigij }\end{array}$ & TotalMigP $2_{i j}$ & TotalMigP1 ${ }_{i j}$ & $\begin{array}{l}\text { TotalMigPi }_{i j}+ \\
\text { Disti }_{+}+\text {ComLang }_{i j} \\
+ \text { Contig } g_{j j}\end{array}$ & TotalMigP $2_{i j}$ & TotalMigP1ij & $\begin{array}{l}\text { TotalMigP1 } 1_{i j}+ \\
\text { Disti }^{+} \text {ComLang } \\
\quad+\text { Contig }_{i j}\end{array}$ & TotalMigP2 $2_{i j}$ \\
\hline \multicolumn{10}{|c|}{ First stage results (partial correlations) } \\
\hline TotalMig & $\begin{array}{l}0.0002^{\mathrm{a}} \\
(0.0000)\end{array}$ & $\begin{array}{l}0.0002^{\mathrm{a}} \\
(0.0000)\end{array}$ & $\begin{array}{l}0.0014^{a} \\
(0.0001)\end{array}$ & $\begin{array}{l}0.0002^{\mathrm{a}} \\
(0.0000)\end{array}$ & $\begin{array}{c}0.0002^{\mathrm{a}} \\
(0.0000)\end{array}$ & $\begin{array}{l}0.0014^{a} \\
(0.0001)\end{array}$ & $\begin{array}{l}0.0001^{\mathrm{a}} \\
(0.0000)\end{array}$ & $\begin{array}{l}0.0001^{\mathrm{a}} \\
(0.0000)\end{array}$ & $\begin{array}{l}0.0011^{\mathrm{a}} \\
(0.0001)\end{array}$ \\
\hline Dist $_{i j}$ & & $\begin{array}{l}-0.0145^{\mathrm{d}} \\
(0.0096)\end{array}$ & & & $\begin{array}{l}-0.0145^{\mathrm{d}} \\
(0.0096)\end{array}$ & & & $\begin{array}{l}-0.0265^{a} \\
(0.0063)\end{array}$ & \\
\hline ComLang $_{i j}$ & & $\begin{array}{l}0.1294^{a} \\
(0.0209)\end{array}$ & & & $\begin{array}{l}0.1294^{a} \\
(0.0209)\end{array}$ & & & $\begin{array}{l}0.0943^{a} \\
(0.0126)\end{array}$ & \\
\hline Contig $_{i j}$ & & $\begin{array}{l}-0.0517 \\
(0.0334)\end{array}$ & & & $\begin{array}{l}-0.0517 \\
(0.0334)\end{array}$ & & & $\begin{array}{l}-0.0606^{\mathrm{b}} \\
(0.0260)\end{array}$ & \\
\hline
\end{tabular}

RelPrimSchool1990 ${ }_{i j}$, RelTertSchool1990 $i j$, Rellnvest1990 ${ }_{i j}$ and RelUrban1990 ${ }_{i j}$ as additional control variables. 
Table 5

Effect of high skilled emigration rates in 1990 on income differences between countries (use of proxies)

\begin{tabular}{|c|c|c|c|c|c|c|c|c|c|}
\hline \multirow[t]{2}{*}{ Variable } & $\begin{array}{l}I V \\
\text { (1) }\end{array}$ & $\begin{array}{l}I V \\
(2)\end{array}$ & $\begin{array}{l}I V \\
(3)\end{array}$ & $\begin{array}{l}I V \\
(4)\end{array}$ & $\begin{array}{l}I V \\
(5)\end{array}$ & $\begin{array}{l}I V \\
(6)\end{array}$ & $\begin{array}{l}I V \\
\text { (7) }\end{array}$ & $\begin{array}{l}I V \\
(8)\end{array}$ & $\begin{array}{l}I V \\
(9)\end{array}$ \\
\hline & \multicolumn{3}{|c|}{ Dependent variable: ${\text { RelWage } 80_{\mathrm{ij}}}$} & \multicolumn{3}{|c|}{ Dependent variable: $\mathbf{R e l W a g e} \mathbf{9 0}_{\mathrm{ij}}$} & \multicolumn{3}{|c|}{ Dependent variable: $\mathbf{R e l G D P}_{\mathrm{ij}}$} \\
\hline Mig1990 $_{i j}$ & $\begin{array}{l}0.7438^{a} \\
(0.1960)\end{array}$ & $\begin{array}{l}0.6243^{a} \\
(0.2158)\end{array}$ & $\begin{array}{l}0.3774^{b} \\
(0.1592)\end{array}$ & $\begin{array}{l}0.7800^{a} \\
(0.1827)\end{array}$ & $\begin{array}{l}0.6422^{\mathrm{a}} \\
(0.2257)\end{array}$ & $\begin{array}{l}0.4173^{a} \\
(0.1485)\end{array}$ & $\begin{array}{l}0.5905^{\mathrm{a}} \\
(0.1247)\end{array}$ & $\begin{array}{l}0.3744^{d} \\
(0.2562)\end{array}$ & $\begin{array}{l}0.3381^{b} \\
(0.1666)\end{array}$ \\
\hline Other controls & YES & YES & YES & YES & YES & YES & YES & YES & YES \\
\hline Origin FE & YES & YES & YES & YES & YES & YES & YES & YES & YES \\
\hline $\mathrm{N}$ & 1010 & 1010 & 1010 & 1010 & 1010 & 1010 & 2259 & 2250 & 2259 \\
\hline Adj. R2 & 0.8481 & 0.8484 & 0.8476 & 0.8451 & 0.8455 & 0.8447 & 0.9387 & 0.9384 & 0.9384 \\
\hline Destination clusters & YES & YES & YES & YES & YES & YES & YES & & YES \\
\hline F-Test (first stage) & 15.04 & 15.70 & 16.02 & 15.04 & 15.70 & 16.02 & 14.11 & 14.92 & 15.26 \\
\hline J-Test & - & 0.642 & - & - & 0.407 & - & - & 0.185 & - \\
\hline Instruments used & TotalMigP1 $1_{i j}$ & $\begin{array}{c}\text { TotalMigP1 } \\
\text { Distij }_{i}+ \\
+ \text { ComLangij }_{i j} \\
+ \text { Contigij }_{i j}\end{array}$ & TotalMigP $2_{i j}$ & TotalMigP1 $1_{i j}$ & $\begin{array}{c}\text { TotalMigP }_{i j}+ \\
\text { Disti }+ \text { ComLang }_{i j} \\
+ \text { Contig } g_{j j}\end{array}$ & TotalMigP $2_{i j}$ & TotalMigP1 $1_{i j}$ & $\begin{array}{c}\text { TotalMigP }_{i j}+ \\
\text { Disti }_{i}+\text { ComLang }_{i j} \\
+ \text { Contig } g_{j j}\end{array}$ & TotalMigP $2_{i j}$ \\
\hline \multicolumn{10}{|c|}{ First stage results (partial correlations) } \\
\hline TotalMig $g_{i j}$ & $\begin{array}{l}0.0002^{\mathrm{a}} \\
(0.0000)\end{array}$ & $\begin{array}{l}0.0002^{\mathrm{a}} \\
(0.0000)\end{array}$ & $\begin{array}{l}0.0015^{\mathrm{a}} \\
(0.0001)\end{array}$ & $\begin{array}{l}0.0002^{\mathrm{a}} \\
(0.0000)\end{array}$ & $\begin{array}{c}0.0002^{\mathrm{a}} \\
(0.0000)\end{array}$ & $\begin{array}{l}0.0015^{\mathrm{a}} \\
(0.0001)\end{array}$ & $\begin{array}{l}0.0001^{\mathrm{a}} \\
(0.0000)\end{array}$ & $\begin{array}{l}0.0001^{\mathrm{a}} \\
(0.0000)\end{array}$ & $\begin{array}{l}0.0011^{\mathrm{a}} \\
(0.0001)\end{array}$ \\
\hline Dist $_{i j}$ & & $\begin{array}{l}-0.0162 \\
(0.0110)\end{array}$ & & & $\begin{array}{l}-0.0162 \\
(0.0110)\end{array}$ & & & $\begin{array}{l}-0.0266^{a} \\
(0.0066)\end{array}$ & \\
\hline ComLang $_{i j}$ & & $\begin{array}{l}0.1522^{\mathrm{a}} \\
(0.0241)\end{array}$ & & & $\begin{array}{l}0.1522^{\mathrm{a}} \\
(0.0241)\end{array}$ & & & $\begin{array}{l}0.1147^{a} \\
(0.0132)\end{array}$ & \\
\hline Contig $_{i j}$ & & $\begin{array}{l}-0.0628 \\
(0.0385)\end{array}$ & & & $\begin{array}{l}-0.0628 \\
(0.0385)\end{array}$ & & & $\begin{array}{l}-0.0674^{\mathrm{b}} \\
(0.0272)\end{array}$ & \\
\hline
\end{tabular}

Notes: Robust clustered standard errors in parenthesis. ${ }^{a}$ indicates a significance level of below $1 \%$; b indicates a significance level between 1 and $5 \%$; indicates significance level between 5 and $10 \%$; dindicates significance level between 10 and $15 \%$. All estimations include RelPrimSchool1990 ${ }_{i j}$, RelTertSchool1990 $0_{i j}$, Rellnwest1990 $i j$ and RelUrban1990 $0_{i j}$ as additional control variables. 
Table S1

Effect of high skilled emigration rates on income differences between countries

\begin{tabular}{|c|c|c|c|c|c|c|}
\hline \multirow[t]{2}{*}{ Variable } & $\begin{array}{c}I V \\
\text { (1) }\end{array}$ & $\begin{array}{c}I V \\
(2)\end{array}$ & $\begin{array}{c}I V \\
(3)\end{array}$ & $\begin{array}{l}I V \\
\text { (4) }\end{array}$ & $\begin{array}{c}I V \\
(5)\end{array}$ & $\begin{array}{l}I V \\
\text { (6) }\end{array}$ \\
\hline & \multicolumn{2}{|c|}{ Dependent variable: $\mathbf{R e l W a g e} 80_{\mathrm{ij}}$} & \multicolumn{2}{|c|}{ Dependent variable: RelWage $90_{i j}$} & \multicolumn{2}{|c|}{ Dependent variable: $\mathbf{R e l G D P}_{\mathbf{i}}$} \\
\hline $\operatorname{Mig}_{2000_{i j}}$ & $\begin{array}{c}0.1743^{a} \\
(0.0629)\end{array}$ & & $\begin{array}{c}0.1957^{a} \\
(0.0597)\end{array}$ & & $\begin{array}{c}0.1922^{\mathrm{a}} \\
(0.0358)\end{array}$ & \\
\hline Mig1990 $_{i j}$ & & $\begin{array}{c}0.1376^{\mathrm{b}} \\
(0.0655)\end{array}$ & & $\begin{array}{c}0.1554^{b} \\
(0.0675)\end{array}$ & & $\begin{array}{c}0.1524^{\mathrm{b}} \\
(0.0613)\end{array}$ \\
\hline$O E C D_{i}$ & $\begin{array}{l}-1.2225^{a} \\
(0.0561)\end{array}$ & $\begin{array}{l}-1.2231^{a} \\
(0.0561)\end{array}$ & $\begin{array}{l}-1.1299^{a} \\
(0.0539)\end{array}$ & $\begin{array}{l}-1.1305^{a} \\
(0.0539)\end{array}$ & $\begin{array}{l}-1.0241^{\mathrm{a}} \\
(0.0316)\end{array}$ & $\begin{array}{l}-1.0245^{a} \\
(0.0316)\end{array}$ \\
\hline $\operatorname{Region}_{s a_{i}}$ & $\begin{array}{c}-0.1975^{b} \\
(0.0809)\end{array}$ & $\begin{array}{l}-0.1983^{b} \\
(0.0807)\end{array}$ & $\begin{array}{l}-0.0709 \\
(0.0800)\end{array}$ & $\begin{array}{l}-0.0718 \\
(0.0798)\end{array}$ & $\begin{array}{c}0.0176 \\
(0.0281)\end{array}$ & $\begin{array}{c}0.0165 \\
(0.0283)\end{array}$ \\
\hline RegionEap $_{i}$ & $\begin{array}{c}0.0454 \\
(0.0767)\end{array}$ & $\begin{array}{c}0.0439 \\
(0.0769)\end{array}$ & $\begin{array}{l}-0.0011 \\
(0.0648)\end{array}$ & $\begin{array}{l}-0.0028 \\
(0.0651)\end{array}$ & $\begin{array}{c}0.6282^{\mathrm{a}} \\
(0.0373)\end{array}$ & $\begin{array}{c}0.6259^{a} \\
(0.0370)\end{array}$ \\
\hline RelPrimSchool1990 & $\begin{array}{l}-0.5618^{a} \\
(0.1839)\end{array}$ & $\begin{array}{l}-0.5622^{a} \\
(0.1839)\end{array}$ & $\begin{array}{l}-0.4530^{a} \\
(0.1562)\end{array}$ & $\begin{array}{l}-0.4535^{a} \\
(0.1562)\end{array}$ & $\begin{array}{c}0.3225^{a} \\
(0.0310)\end{array}$ & $\begin{array}{c}0.3231^{a} \\
(0.0309)\end{array}$ \\
\hline RelTertSchool1990 $i j$ & $\begin{array}{c}0.0085 \\
(0.0056)\end{array}$ & $\begin{array}{c}0.0085 \\
(0.0056)\end{array}$ & $\begin{array}{c}0.0079 \\
(0.0052)\end{array}$ & $\begin{array}{c}0.0080 \\
(0.0052)\end{array}$ & $\begin{array}{c}0.0037^{\mathrm{a}} \\
(0.0010)\end{array}$ & $\begin{array}{c}0.0038^{a} \\
(0.0010)\end{array}$ \\
\hline RelInvest1990 & $\begin{array}{c}0.1276^{a} \\
(0.0208)\end{array}$ & $\begin{array}{c}0.1276^{a} \\
(0.0209)\end{array}$ & $\begin{array}{c}0.1264^{a} \\
(0.0189)\end{array}$ & $\begin{array}{c}0.1263^{\mathrm{a}} \\
(0.0189)\end{array}$ & $\begin{array}{c}0.0811^{\mathrm{a}} \\
(0.0108)\end{array}$ & $\begin{array}{c}0.0812^{\mathrm{a}} \\
(0.0108)\end{array}$ \\
\hline RelUrban1990 & $\begin{array}{c}0.3758^{a} \\
(0.0521)\end{array}$ & $\begin{array}{c}0.3756^{a} \\
(0.0521)\end{array}$ & $\begin{array}{c}0.3407^{\mathrm{a}} \\
(0.0495)\end{array}$ & $\begin{array}{c}0.3405^{\mathrm{a}} \\
(0.0495)\end{array}$ & $\begin{array}{c}0.1856^{\mathrm{a}} \\
(0.0141)\end{array}$ & $\begin{array}{c}0.1854^{a} \\
(0.0140)\end{array}$ \\
\hline (incercept) & $\begin{array}{l}1.3636^{a} \\
(0.1749)\end{array}$ & $\begin{array}{c}1.3649 \mathrm{a} \\
(0.1748)\end{array}$ & $\begin{array}{l}1.1906^{a} \\
(0.1717)\end{array}$ & $\begin{array}{l}1.1921^{\mathrm{a}} \\
(0.1715)\end{array}$ & $\begin{array}{c}0.4707 a \\
(0.0735)\end{array}$ & $\begin{array}{l}0.4709^{a} \\
(0.0733)\end{array}$ \\
\hline Origin FE & $\mathrm{NO}$ & $\mathrm{NO}$ & $\mathrm{NO}$ & $\mathrm{NO}$ & $\mathrm{NO}$ & $\mathrm{NO}$ \\
\hline $\begin{array}{l}\mathrm{N} \\
\text { Adj. R2 }\end{array}$ & $\begin{array}{c}1010 \\
0.4905\end{array}$ & $\begin{array}{c}1010 \\
0.4904\end{array}$ & $\begin{array}{c}1010 \\
0.4903\end{array}$ & $\begin{array}{c}1010 \\
0.4902\end{array}$ & $\begin{array}{c}2275 \\
0.6725\end{array}$ & $\begin{array}{c}2275 \\
0.6722\end{array}$ \\
\hline
\end{tabular}


Table 52

Effect of high skilled emigration rates on income differences between countries (log emigration stock as instrument)

\begin{tabular}{|c|c|c|c|c|c|c|}
\hline \multirow[t]{2}{*}{ Variable } & $\begin{array}{l}I V \\
(1)\end{array}$ & $\begin{array}{l}I V \\
(2)\end{array}$ & $\begin{array}{l}I V \\
(3)\end{array}$ & $\begin{array}{l}I V \\
(4)\end{array}$ & $\begin{array}{l}I V \\
(5)\end{array}$ & $\begin{array}{l}I V \\
(6)\end{array}$ \\
\hline & \multicolumn{2}{|c|}{ Dependent variable: RelWage $80_{i j}$} & \multicolumn{2}{|c|}{ Dependent variable: $\mathbf{R e l W a g e} \mathbf{9 0}_{\mathrm{ij}}$} & \multicolumn{2}{|c|}{ Dependent variable: $\mathbf{R e l G D P}_{\mathrm{ij}}$} \\
\hline$M_{i g} 2000_{i j}$ & $\begin{array}{c}0.4515^{a} \\
(0.1706)\end{array}$ & $\begin{array}{c}0.2879 a \\
(0.1056)\end{array}$ & $\begin{array}{c}0.4023^{\mathrm{b}} \\
(0.1807)\end{array}$ & $\begin{array}{c}0.2554^{\mathrm{b}} \\
(0.1141)\end{array}$ & $\begin{array}{c}0.2554^{c} \\
(0.1351)\end{array}$ & $\begin{array}{c}0.1141^{\mathrm{c}} \\
(0.0681)\end{array}$ \\
\hline RelPrimSchool1990 $_{i j}$ & $\begin{array}{l}-0.8013 \\
(1.9769)\end{array}$ & $\begin{array}{l}-0.8561 \\
(2.0852)\end{array}$ & $\begin{array}{l}-0.3685 \\
(1.8476)\end{array}$ & $\begin{array}{l}-0.4155 \\
(1.9356)\end{array}$ & $\begin{array}{l}-0.3943 \\
(0.7558)\end{array}$ & $\begin{array}{l}-0.4430 \\
(0.7662)\end{array}$ \\
\hline RelTertSchool1990 $i j$ & $\begin{array}{l}-0.0015 \\
(0.0074)\end{array}$ & $\begin{array}{c}0.0031 \\
(0.0083)\end{array}$ & $\begin{array}{l}-0.0002 \\
(0.0072)\end{array}$ & $\begin{array}{c}0.0039 \\
(0.0081)\end{array}$ & $\begin{array}{c}0.0018 \\
(0.0023)\end{array}$ & $\begin{array}{c}0.0033 \\
(0.0025)\end{array}$ \\
\hline RelInvest1990 & $\begin{array}{c}0.6068^{a} \\
(0.2234)\end{array}$ & $\begin{array}{c}0.5673^{\mathrm{b}} \\
(0.2350)\end{array}$ & $\begin{array}{c}0.5307^{b} \\
(0.2162)\end{array}$ & $\begin{array}{c}0.4958^{\mathrm{b}} \\
(0.2263)\end{array}$ & $\begin{array}{c}0.2391^{b} \\
(0.1096)\end{array}$ & $\begin{array}{c}0.2393^{b} \\
(0.1155)\end{array}$ \\
\hline RelUrban1990 & $\begin{array}{c}0.6805^{\mathrm{b}} \\
(0.2699)\end{array}$ & $\begin{array}{c}0.6732^{\mathrm{b}} \\
(0.2843)\end{array}$ & $\begin{array}{c}0.5947^{\mathrm{b}} \\
(0.2723)\end{array}$ & $\begin{array}{c}0.5886^{\mathrm{b}} \\
(0.2843)\end{array}$ & $\begin{array}{c}0.1831^{\mathrm{b}} \\
(0.0830)\end{array}$ & $\begin{array}{c}0.1934^{b} \\
(0.0822)\end{array}$ \\
\hline (incercept) & $\begin{array}{c}0.2245 \\
(2.4135)\end{array}$ & $\begin{array}{c}0.3700 \\
(2.5428)\end{array}$ & $\begin{array}{l}-0.0789 \\
(2.3583)\end{array}$ & $\begin{array}{c}0.0481 \\
(2.4650)\end{array}$ & $\begin{array}{c}3.8160 \\
(3.0059)\end{array}$ & $\begin{array}{c}3.9724 \\
(3.0644)\end{array}$ \\
\hline Origin FE & YES & YES & YES & YES & YES & YES \\
\hline $\mathrm{N}$ & 1010 & 1010 & 1010 & 1010 & 2275 & 2266 \\
\hline Adj. R2 & 0.8675 & 0.8583 & 0.8624 & 0.8541 & 0.9425 & 0.9411 \\
\hline Destination clusters & YES & YES & YES & YES & YES & YES \\
\hline F-Test (first stage) & 14.84 & 18.2 & 14.84 & 18.2 & 18.05 & 19.96 \\
\hline J-Test & & 0.312 & & 0.242 & & 0.315 \\
\hline Instruments used & LogEmigrationStock ${ }_{i j}$ & $\begin{array}{c}\text { LogEmigrationStock }_{i j}+ \\
\text { Dist }_{i}+\text { ComLang }_{g_{i j}}+ \\
\text { Contig }_{i j}\end{array}$ & LogEmigrationStockeij & $\begin{array}{c}\text { LogEmigrationStock }_{i j}+ \\
\text { Dist }_{i}+\text { ComLang }_{i j}+ \\
\text { Contig }_{i j}\end{array}$ & LogEmigrationStock & $\begin{array}{c}\text { LogEmigrationStock }_{i j}+ \\
\text { Dist }_{i}+\text { ComLang }_{i j}+ \\
\text { Contigij }_{i j}\end{array}$ \\
\hline
\end{tabular}


Table 53

Effect of high skilled emigration rates on income differences between countries (Proxy constructed with Defoort, 2006 emigration rates)

\begin{tabular}{|c|c|c|c|c|c|c|}
\hline \multirow[t]{2}{*}{ Variable } & $\begin{array}{l}I V \\
(1)\end{array}$ & $\begin{array}{l}I V \\
(2)\end{array}$ & $\begin{array}{l}I V \\
(3)\end{array}$ & $\begin{array}{l}I V \\
(4)\end{array}$ & $\begin{array}{l}I V \\
(5)\end{array}$ & $\begin{array}{l}I V \\
(6)\end{array}$ \\
\hline & \multicolumn{2}{|c|}{ Dependent variable: RelWage $\mathbf{~}_{\mathrm{ij}}$} & \multicolumn{2}{|c|}{ Dependent variable: RelWage $90_{\mathrm{ij}}$} & \multicolumn{2}{|c|}{ Dependent variable: $\mathbf{R e l G D P}_{\mathbf{i j}}$} \\
\hline $\mathrm{Mig}^{2000_{i j}}$ & $\begin{array}{l}0.5337^{a} \\
(0.1733)\end{array}$ & $\begin{array}{l}0.3056^{\mathrm{b}} \\
(0.1536)\end{array}$ & $\begin{array}{l}0.5579^{a} \\
(0.1728)\end{array}$ & $\begin{array}{l}0.3540^{\mathrm{b}} \\
(0.1723)\end{array}$ & $\begin{array}{l}0.3437 \mathrm{c} \\
(0.1817)\end{array}$ & $\begin{array}{l}0.3619^{\mathrm{b}} \\
(0.1835)\end{array}$ \\
\hline RelPrimSchool1990 $i j$ & $\begin{array}{l}-1.1455 \\
(2.2607)\end{array}$ & $\begin{array}{l}-1.1571 \\
(2.2688)\end{array}$ & $\begin{array}{l}-0.6793 \\
(2.0744)\end{array}$ & $\begin{array}{l}-0.6898 \\
(2.0816)\end{array}$ & $\begin{array}{l}-0.4362 \\
(0.7925)\end{array}$ & $\begin{array}{l}-0.4356 \\
(0.7941)\end{array}$ \\
\hline RelTertSchool1990 $i j$ & $\begin{array}{c}0.0093 \\
(0.0096)\end{array}$ & $\begin{array}{c}0.0099 \\
(0.0099)\end{array}$ & $\begin{array}{c}0.0091 \\
(0.0093)\end{array}$ & $\begin{array}{c}0.0097 \\
(0.0096)\end{array}$ & $\begin{array}{c}0.0043 \\
(0.0027)\end{array}$ & $\begin{array}{c}0.0042 \\
(0.0026)\end{array}$ \\
\hline Rellnvest1990 & $\begin{array}{l}0.4785^{c} \\
(0.2477)\end{array}$ & $\begin{array}{l}0.4726^{c} \\
(0.2481)\end{array}$ & $\begin{array}{c}0.4178^{c} \\
(0.2373)\end{array}$ & $\begin{array}{l}0.4125^{c} \\
(0.2382)\end{array}$ & $\begin{array}{l}0.2235^{c} \\
(0.1185)\end{array}$ & $\begin{array}{c}0.2241^{c} \\
(0.1182)\end{array}$ \\
\hline RelUrban1990 & $\begin{array}{c}0.6171^{\mathrm{b}} \\
(0.2996)\end{array}$ & $\begin{array}{c}0.6158^{b} \\
(0.3002)\end{array}$ & $\begin{array}{c}0.5382^{c} \\
(0.2956)\end{array}$ & $\begin{array}{c}0.5371^{c} \\
(0.2964)\end{array}$ & $\begin{array}{c}0.1975^{\mathrm{b}} \\
(0.0798)\end{array}$ & $\begin{array}{c}0.1976^{\mathrm{b}} \\
(0.0794)\end{array}$ \\
\hline (incercept) & $\begin{array}{c}0.8965 \\
(2.7392)\end{array}$ & $\begin{array}{c}0.9219 \\
(2.7514)\end{array}$ & $\begin{array}{c}0.5209 \\
(2.6180)\end{array}$ & $\begin{array}{c}0.5436 \\
(2.6292)\end{array}$ & $\begin{array}{c}3.9614 \\
(3.1712)\end{array}$ & $\begin{array}{c}3.9575 \\
(3.1781)\end{array}$ \\
\hline Origin FE & YES & YES & YES & YES & YES & YES \\
\hline $\mathrm{N}$ & 932 & 932 & 932 & 932 & 2250 & 2259 \\
\hline Adj. R2 & 0.8539 & 0.8531 & 0.8516 & 0.8508 & 0.9424 & 0.9424 \\
\hline Destination clusters & YES & YES & YES & YES & YES & YES \\
\hline F-Test (first stage) & 15.22 & 17.33 & 15.22 & 17.3 & 14.804 & 14.43 \\
\hline J-Test & 0.9377 & & 0.7770 & & 0.4656 & \\
\hline Instruments used & DefoortTotalMig $1_{i j}$ & $\begin{array}{c}\text { DefoortTotalMig }_{i j}+\text { Dist }_{i} \\
\quad+\text { ComLang }_{g i j}+\text { Contig }_{i j} \\
\end{array}$ & DefoortTotalMig2 ${ }_{i j}$ & DefoortTotalMig $1_{i j}$ & $\begin{array}{c}\text { DefoortTotalMig }_{i j}+\text { Dist }_{i} \\
\quad+\text { ComLang }_{g i j}+\text { Contig }_{g i j} \\
\end{array}$ & DefoortTotalMig $2_{i j}$ \\
\hline
\end{tabular}

Instruments constructed as described in text but with Defoort (2006) data on emigration instead of the United Nations Population Division. 


\title{
Authors
}

Volker GROSSMANN

University of Fribourg; CESifo, Munich; and Institute for the Study of Labor (IZA), Bonn. Postal adress: University of Fribourg, Department of Economics, Bd. de Pérolles 90, G424, 1700 Fribourg,Switzerland. Tel.: +41 (0)26 3009383. Email: volker.grossmann[at]unifr.ch

\section{David STADELMANN}

University of Fribourg, Department of Economics, Bd. de Pérolles 90, F410, 1700 Fribourg, Switzerland. Tel.: +41 (0)26 3009382. Email: david.stadelmann[at]unifr.ch

\begin{abstract}
This paper argues that international migration of high-skilled workers triggers productivity effects at the macro level such that the wage rate of skilled workers may well rise in host countries and decline in source countries.

We exploit a recent data set on international bilateral migration flows and provide evidence which is consistent with this hypothesis.

In order to identify the causal effect of migration on wages, we propose different instrumentation strategies which address the endogeneity problem arising from the fact that international wage differences affect migration decisions.
\end{abstract}

\section{Keywords}

High-skilled migration; Wage effects; Total factor productivity

\section{JEL Classification}

$\mathrm{F} 22, \mathrm{O} 30$

\section{Citation proposal}

Grossmann Volker, Stadelmann David. 2010. «Wage Effects of High-skilled Migration: International Evidence». Working Papers SES 415, Faculty of Economics and Social Sciences, University of Fribourg (Switzerland)

\section{Working Papers SES}

Last published :

408 Dumont P.-A., Isakov D.: Les rachats d'actions en Suisse. Objectifs, conséquences et pratiques; 2009

409 Friboulet J.-J.: Attractivité et économie géographique : une première approche, 2009

410 Biwolé Fouda, J.: Privatisation des Industries de Réseaux et développement durable : le cas du Cameroun; 2010

411 Friboulet J.-J.: La théorie néoclassique et le développement durable; 2010

412 Rohe A., Grünig R.: Strategie unter Unsicherheit; 2010

413 Grossmann V., Stadelmann D.: Does High-Skilled Migration Affect Publicly Financed Investments?; 2010

414 Grossmann V., Seger T., Trimborn T.: Quantifying Optimal Growth Policy; 2010

\section{Catalogue and download links:}

http://www.unifr.ch/ses/wp

http://doc.rero.ch/collection/UNIFR WORKING PAPERS SES 